\title{
Anal Cancer pT3 TNM Finding v8
}

National Cancer Institute

\section{Source}

National Cancer Institute. Anal Cancer pT3 TNM Finding v8. NCI Thesaurus. Code C133776.

Anal cancer with tumor larger than $5 \mathrm{~cm}$. (from AJCC 8th Ed.) 